\title{
Farmers' Attitudes about Farming and the Environment: A Survey of Conventional and Organic Farmers
}

\author{
SHANNON SULLIVAN \\ School of Natural Resources and Environment \\ University of Michigan \\ 430 East University Avenue \\ Ann Arbor, Michigan 48109-1115 USA \\ ELIZABETH MCCANN \\ College of Natural Resources \\ University of Wisconsin Stevens Point \\ Stevens Point, Wisconsin 54481-3897 USA
}

RAYMOND DE YOUNG and DONNA ERICKSON

School of Natural Resources and Environment

University of Michigan

430 East University Avenue

Ann Arbor, Michigan 48109-1115 USA

\begin{abstract}
Farmers have been characterized as people whose ties to the land have given them a deep awareness of natural cycles, appreciation for natural beauty and sense of responsibility as stewards. At the same time, their relationship to the land has been characterized as more utilitarian than that of others who are less directly dependent on its bounty. This paper explores this tension by comparing the attitudes and beliefs of a group of conventional farmers to those of a group of organic farmers. It was found that while both groups reject the idea that a farmer's role is to conquer nature, organic farmers were significantly more supportive of the notion that humans should live in harmony with nature. Organic farmers also reported a greater awareness of and appreciation for nature in their relationship with the land. Both groups view independence as a main benefit of farming and a lack of financial reward as its main drawback. Overall, conventional farmers report more stress in their lives although they also view themselves in a caretaker role for the land more than do the organic farmers. In contrast, organic farmers report more satisfaction with their lives, a greater concern for living ethically, and a stronger perception of community. Finally, both groups are willing to have their rights limited (organic farmers somewhat more
\end{abstract}


so) but they do not trust the government to do so.

Keywords: environmental attitudes, organic farming, environmental ethics.

\section{Introduction}

Until recently, the United States has been a fundamentally agrarian society. Because of this, agriculture has always been central in debates about land-use ethics. The agrarian tradition and the land ethic comprise two distinct and conflicting threads of thought regarding agriculture. The first is rooted in Thomas Jefferson's concept of a stable democracy of yeoman farmers, where "... those who labor in the earth are the chosen people of God ... whose breasts he has made his peculiar deposit for substantial and genuine virtue" (Meine, 1987; Jefferson in Peterson, 1991: 293).

The second philosophical thread may have been born when humans initiated a struggle with nature by purposely cultivating certain plant species as crops (Wojcik, 1989). The American tradition of mythicizing this struggle, and sanctioning the exploitation of natural resources, began with the pioneers. However, almost concurrently, some writers and philosophers began questioning the ethics of gaining dominion over nature. This philosophy was initiated by Tocqueville and Cooper, justified by Darwin, articulated poetically by the transcendentalists and refined to a science by Aldo Leopold. Contemporary literature - both philosophical and scientific-has attempted to define further and even operationalize these competing views.

While the tension between these two traditions may be abstract, its impact is not. These competing philosophies have become encoded in our language and have formed the foundations of how Americans think about and act toward the environment (Peterson, 1991). Today, these conflicting philosophies are at the root of a policy debate regarding the sanctity of private property, the value of family farms, and the effectiveness of agricultural education and incentive programs for farmers.

\section{Jeffersonian Agrarianism and the American Frontier}

Agrarian sentiments can be traced as far back as Aristotle and Cicero, but Thomas Jefferson is the best known American exponent of these ideals (Molnar and Duffy, 1987). Jefferson believed agriculture was fundamental to the American way of life, and that small landholders were civilization's caretakers (Peterson, 1991; Little, 1985). An important part of the agrarian or Jeffersonian creed is that farmers have a right to use the land as they please, and that society's and individual property owners' interests are one and the same (Bultena et al., 1981). The French-born American St. John Crevecoeur also wrote idealistically of the virtues of agricultural life in America. As a farmer, he was proud to be part of a community of "freeholders, the possessors of the soil they cultivate, members of the government they obey, and the framers of their own laws by means of their representative" (Crevecoeur, 1904). 
The agrarian values espoused by Jefferson and Crevecoeur also formed the basis of rugged individualism in the west (Molnar and Duffy, 1987), where the pioneers were pitted against nature in a struggle for their very survival. As Alexis de Tocqueville observed in Democracy in America, the pioneers lived too close to the wilderness to appreciate it; their main concern was the utility of the land (Nash, 1982). Wherever the pioneers "... encountered wild country they viewed it through utilitarian spectacles: trees became lumber, prairies farms, and canyons the sites of hydroelectric dams" (Nash, 1982). Utilitarianism was also the prevailing political theme of the time. In his 1830 inaugural address, Andrew Jackson asked, "what good man would prefer a country covered with forests and ranged by a few thousand savages to our extensive Republic, studded with cities, towns, and prosperous farms?" (Nash, 1982: 41).

\section{The Land Ethic}

Aldo Leopold is thought of as the first to write explicitly about a land ethic, especially in farming. Because his essays combined the sensitivity of a romantic with the logic of a scientist, his influence in encouraging a new relationship between humans and the land was arguably more profound than that of his predecessors (Nash, 1982). Leopold was educated in the tradition of utilitarianism at the Yale Forestry School and in the U.S. Forest Service (Hargrove and Callicott, 1990). However, as his career progressed and his philosophy developed, Leopold rejected utilitarianism and embraced aesthetics.

Sometimes I think that ideas, like men, can become dictators. We Americans have so far escaped regimentation by our rulers, but have we escaped regimentation by our own ideas? I doubt if there exists today a more complete regimentation of the human mind than that accomplished by our self-imposed doctrine of ruthless utilitarianism. (Leopold in Meine, 1987: 49)

To replace the ruthless utilitarianism born of the frontier experience, Leopold proposed a new ethic to govern humanity's relationship with the land. He argued for the intrinsic rights of all species, and against the Jeffersonian idea that private property was enough to ensure sustainable land use. "In short," Leopold wrote, "a land ethic changes the role of Homo sapiens from conqueror of the land-community to plain member and citizen of it. It implies respect for his fellow-members, and also respect for the community as such" (Leopold, 1949: 204). Leopold's philosophy of the land ethic developed over a lifetime, but it became focused in one parsimonious statement: "A thing is right when it tends to preserve the integrity, stability, and beauty of the biotic community. It is wrong when it tends otherwise" (Leopold, 1949: xxvi).

Leopold's holistic philosophy was as radical as any that preceded him, yet he did not reject the concept of agriculture outright. In fact, Leopold was a farmer in his later years. Regardless of his motivation, Leopold paid special attention to the role of farming in humanity's relationship with nature (Meine, 1987). Leopold believed 
the "rightness" of farming depended on the farmer (Meine, 1987). He identified two opposing philosophies of farm life. According to one philosophy, "the farm is a foodfactory, and the criterion of its success is salable products." According to the second philosophy, "the farm is a place to live, and the criterion of success is a harmonious balance between plants, animals, and people; between the domestic and the wild; between utility and beauty" (Leopold, 1949 in Meine, 1987: 51). Forty years later, Wojcik defined the two principles of agriculture as: farming strictly for the money and farming for a good life (Wojcik, 1989).

\section{The Legacy: Conflicting Views of Agriculture}

Remarkably, the conflicting images of agriculture preserved in our literary tradition have co-existed in the national psyche for over two centuries. This cultural tradition of simultaneously mythicizing the farmer as steward and the pioneer as conqueror has left a legacy of internal conflict for farmers and non-farmers. An adversarial relationship between environmentalists and agricultural producers has also emerged from this tradition.

Indeed, both the frontier myth of the pioneer as the creator of civilization and the agrarian myth of the farmer as steward are alive and well in contemporary American thought (Peterson, 1991; Nash, 1982; Piasecki, 1982; Bultena et al., 1981; Lewisohn, Ludwig in Crevecoeur, 1904). Although the children and grandchildren of the pioneers began to sense the ethical and aesthetic values of wilderness, the prejudice against wilderness is deeply embedded in American history and continues to influence people's attitudes (Nash, 1982). The farmer is the living example of pioneer spirit: "Just as the frontiersman cleared a trail for civilization to follow, today's farmer recivilizes the land year after year, dredging sustenance for city dwellers from the soil. Each season brings renewed encroachment from 'wild' plants or animals, and each season farmers fight back with sophisticated tools provided by the civilization they make possible" (Peterson, 1991: 298).

If asked, "Is there something special about farmers and the farm way of life?" and then separately, "Do you think agriculture is contributing to this country's environmental problems?" many Americans would not have to think long before responding "Of course and, well, yes." It is increasingly common to see publications such as a 1982 U.S. Department of Commerce report titled "Diverging Interests in Soil Conservation and Water Quality: Society vs. the Farmer" (Crosson, 1982). At the same time, the country's romance with farming is easily seen. In New York City, people pack the farmers' markets, eager for contact with the farmer and thereby a connection to the earth and the labor that produces sustenance. As one buyer puts it, "When you buy this food ... you get the sense that life is still good, that life makes sense" (Hall, 1992). This somewhat romantic view of farmers even softens criticism about their behaviour. As Westmacott (1983: 14) observes, "In view of the history of land exploitation one might expect Americans to have a deep distrust of farmers but it isn't so. Perhaps it is because of belief in the ethic that land ownership includes the right to use or misuse the land ... It is ironic that in the United States, where there has never been a tradition of conservation farming, the farmer is trusted as 
the steward of the rural landscape."

These conflicting images of farming may have been internalized by the farmers themselves, creating what Peterson (1991) calls a dysfunctional perspective toward conservation. She argues that farmers simultaneously see themselves as stewardswith a duty to care for the soil - and frontiersmen - with a responsibility to manipulate and control the soil. These conflicting values constantly compete for pre-eminence within the farmer. Efforts to encourage conservation often confound this struggle by failing to take into account farmers' conflicting motives (Peterson, 1991).

Despite the hold agriculture has on the nation's collective imagination, the relationship between agricultural and environmental groups today is far from a romance. The contemporary environmental movement's moral foundation is the minority tradition of thinkers like Leopold, not the agrarianism of Jefferson (Callicott, 1987; Flader, 1987; Stegner, 1985; Nash, 1987). Although it may be changing, the movement's traditional followers have also been a minority of young, wealthy urbanites (Nash, 1982). Philosophically, the division has been between those who argue for appreciation and preservation ("beauty," as Leopold would call it) versus those who advocate utilization of natural resources (Bultena et al., 1982; Hendee, $1969 ;$ Nash, 1982). In a nation divided between those who depend on the harvesting of natural resources for their livelihoods, and those who work in industries far removed from the natural environment, the resiliency of this historic argument is understandable, if unfortunate.

\section{Exploring Farmers' Values and Beliefs}

It would be useful, then, to examine how these competing philosophies express themselves in modern farmers values and beliefs. For only if we fully understand the attitudes and motives of farmers can we ever hope to promote more environmentally sound agriculture. Numerous studies have concluded that farmers are generally less concerned about the environment than non-farmers, but the variation among farmers is great (Buttel et al., 1981). Only a few studies have attempted to explain this variation by examining the basic beliefs and values of conventional and alternative agriculturists (Beus and Dunlap, 1991; Harris et al., 1980; Buttel and Gillespie, 1988).

Beus and Dunlap (1990; 1991) suggest that the fundamental rift between supporters and critics of modern industrialized agriculture is rooted in conflicting worldviews. They have measured the two perspectives - the "alternative agriculture paradigm" and the "conventional agriculture paradigm" - using six dimensions. The dimensions included Domination of Nature vs. Harmony with Nature, and Exploitation vs. Restraint. In their study to determine what factors discriminate between known groups of farmers, the alternative agriculturists differed significantly from conventional agriculturists and a statewide farmer sample on all items measured, with the alternative agriculturists tending toward the "alternative agriculture paradigm." The greatest discrepancy was found on items measuring whether farming is first and foremost a business or a way of life, whether agriculture is a major or minor cause of ecological problems, and whether farming involves trying to imitate 
nature or overcome nature's limits.

Although Beus and Dunlap's findings support the theory that alternative and conventional farmers have fundamentally different values and beliefs, conventional growers are not uniformly anti-environmental. In Molnar and Duffy's (1987) study, farmers generally agreed that "farming involves understanding and working with nature." Most British farmers interviewed by Carr and Tait (1991) had favourable attitudes toward conservation when it was discussed in general terms. Anderson's (1990) research revealed that conventional farmers are deeply concerned about the potential effects of groundwater pollution on their families' health. However, Buttel et al. (1981) found conventional farmers to be less concerned about agricultural chemical pollution than alternative farmers. Based on their findings that concern with agricultural chemical pollution and concern with soil erosion are virtually independent, Buttel et al. (1981) concluded that "agrarian environmentalism" is not a singular construct or dimension.

This paper builds from this previous research by exploring two main themes. First, we hypothesize that both organic and conventional farmers demonstrate an appreciation of nature in a general sense, and view particular signs of nature as important to their farming practices. Second, we expect that organic and conventional farmers exhibit fundamentally different values with regard to the land. Specifically, we expect conventional farmers to embrace the frontier mentality that humans should overcome nature, and the Jeffersonian belief in the rights of landholders. We expected organic farmers to believe in living harmoniously with nature and to be less concerned with their rights as landholders.

\section{Method}

A personal interview was administered to a sample group of 25 farmers in southeastern Michigan. A list of farmers' names and addresses was purchased from the Washtenaw County office of the Natural Resource Conservation Service (previously the Soil Conservation Service). The list included all those individuals who were farm owners and/or farm operators in the county, and these were considered to be "conventional" in their farming practices. Twenty-four names were chosen at random. The organic farmers' names and addresses were derived from the 1991 roster of the Southeast Chapter of the Organic Growers of Michigan (OGM). "Organic" farmers are defined, for the purposes of this study, as "farmers who avoid use of any synthetic or manufactured substances in growing their crops and managing their land" (Esseks et al., 1990). All the organic growers listed in the OGM roster with addresses within or near Washtenaw County were contacted to be interviewed.

A combination of qualitative and quantitative methods were used. For the quantitative method (covered in the first three tables discussed below), groups of fivepoint Likert scale statements were examined using factor analysis and the t-test statistic. The remainder of the findings were derived from the qualitative analysis of standardized, open-ended questions. Following a pre-test of the survey instrument, the farmers were contacted by letter to explain the study and to invite their participation. Mailed at the end of March, the letter was then followed by a phone 
call to determine agreement about being interviewed and to set up a meeting time and place. Interviews occurred during an eight week period, from April through June. A total of 39 farmers were asked to participate. Of these, some farmers declined to be interviewed or were retired from farming. The final sample size was 25 farmers, of whom 13 were conventional and 12 were organic farmers.

As recommended by Patton (1990), the qualitative analysis was performed in two parts: a descriptive case study of each farmer, and a cross-case interpretation of farm operators' responses to each open-ended question. The case study provides a description of each farmer; a profile constructed from their responses and the interviewer's strong impressions of the interview as a whole. The cross-case interpretation was based on a series of categories derived from the data. The categories were created from patterns found in responses to each question, with an emphasis on indigenous concepts (concepts specifically named by the participants, such as "Enjoying being outdoors"). Categories were constructed such that they were internally homogenous (i.e. the data in a category clearly belonged together) and externally heterogeneous (i.e. the categories were clearly different from each other) (Patton, 1990). In analysing the data, concepts that were included with markedly different frequency in responses given by organic and conventional farmers, and concepts that were highly endorsed by both groups of farmers, were reported as findings of the study.

\section{Results}

\section{Demographic Profile of the Sample}

The farmers surveyed differed in terms of their years farming, farm size, land tenure, and number of crops. They were similar along several other dimensions, including age, education, and percentage of income derived from farming in 1991. Mean ages were 46 and 50 years for organic and conventional farmers, respectively. The lack of any significant difference between the ages of the organic and conventional farmers is consistent with Napier and Forster's (1982) conclusion that age has no influence on a farmer s inclination to adopt new conservation practices. The typical farmer in this study had some college education, but less than a college degree. Roughly half of the income from the farm families studied came from farming (43.6\% for organic farmers and $58.2 \%$ for conventional farmers).

There was a significant difference between the two groups with regard to the number of years farming, with conventional farmers having a mean of 30.2 years and organic farmers having a mean of 15.5 years $(t=2.98, d f=22.9, p \leq .01)$. The findings regarding farm structure also reveal several differences within this sample. The dats suggest the organic farmers typically had smaller farms with greater crop diversity than conventional farmers. Conventional farmers also differed significantly from organic farmers in the number of acres owned. While conventional farmers had a mean of 229.4 acres owned, organic farmers had a mean of 74.1 acres owned $(t=2.58, d f=16.5, p \leq .05)$. Similarly, conventional farmers differed significantly $(t=2.17, d f=13.7, p \leq .05)$ from organic farmers in the numbers of acres leased; conventional farmers leased more acres (mean $=482$ ) than organic farmers 
(mean $=65$ ). Organic farmers and conventional farmers also differed significantly in the number of crops grown in $1991(t=2.92, d f=20.1, p \leq .01)$; organic farmers grew a greater variety of crops (mean $=6.25$ ) than did conventional farmers $($ mean $=3.92)$.

For the most part, the conventional farmers studied were from a family tradition of farming, while organic farmers tended to be relatively new to farming as a career. All conventional farmers were from families that had almost always been involved in farming. In contrast, only $25 \%$ of the organic farmers were from such a background.

\section{Frontier Mentality Attitudes}

Using factor analysis, four categories were derived from a series of 14 "frontier mentality" questions. ${ }^{1}$ These include a Harmony category, a Disaster category, a Right category, and an Order category (see Table 1). Pairwise $t$-tests indicate that higher means for the Harmony category and the Disaster category suggests that farmers were inclined to agree more strongly with the statements within those categories. The Harmony and Disaster categories did not differ significantly from one another $(p \leq .05)$, suggesting that farmers tended to answer similarly to these statements. Likewise, the means for the Right and Order categories were not significantly different from one another $(p \leq .05)$.

Alpha values were also calculated for the four new "frontier mentality" attitude categories (see Table 1). Alpha is Cronbach's (1951) coefficient of internal consistency and reflects the degree of cohesiveness among a group of items. Two of the categories (i.e. Disaster, Right) have only one item and, therefore, no alpha value. Harmony had five items and an alpha value of 0.82 , indicating that the category is very coherent. The Order category has three items and a relatively low alpha of 0.49 which indicates the items are not as tightly connected.

Comparisons between organic and conventional farmers were made with regard to the aforementioned categories using a Student's $t$-test (see Table 2). Organic farmers had a significantly higher mean for the Harmony category than conventional farmers $(t=4.17, d f=21.2, p \leq .0001)$, suggesting that organic farmers endorsed the statements within that category more strongly. Organic and conventional farmers did not differ significantly with regard to the Disaster, Right, and Order categories.

Among organic farmers, pairwise $t$-tests indicate that the mean responses for the Harmony and Order categories were significantly different from one another at $p \leq$ .05. Although their responses for the Harmony, Disaster, and Right categories were not significantly different $(p \leq .05)$, all three of these items varied significantly from the Order category. And while organic farmers mean responses to the Right and Order categories did not differ at $p .<05$ their responses to the Harmony and Right categories barely missed being significantly different $(p \leq .06)$. All pairwise mean comparisons among conventional farmers' responses were not significant at $p$. < 05 . Thus, while the conventional farmers' responses were generally close to neutral for all four categories, organic farmers tended to endorse Harmony and Disaster 
Table 1

Categories of "frontier mentality" attitudes

\begin{tabular}{|c|c|c|c|}
\hline Category Name and Items Included & Mean (a) & S.D. & Alpha \\
\hline $\begin{array}{l}\text { HARMONY } \\
\text { - Humans must live in harmony with nature in order to survive } \\
\text { - Humankind was created to rule over the rest of nature (b) } \\
\text { - Farm operators do not have the right to farm land in a manner } \\
\text { that will cause damage to the resource } \\
\text { - Humans have the power to improve upon nature, by } \\
\text { cultivating it and making it productive (b) } \\
\text { - Humans need not adapt to the natural environment because } \\
\text { they can remake it to suit their needs (b) }\end{array}$ & $3.72^{\mathrm{a}}$ & 0.78 & 0.82 \\
\hline $\begin{array}{l}\text { DISASTER } \\
\text { - When humans interfere with nature it often produces } \\
\text { disastrous consequences }\end{array}$ & $3.75^{\mathrm{a}}$ & 1.11 & $-\cdot$ \\
\hline $\begin{array}{l}\text { RIGHT } \\
\text { - Humans have the right to modify the natural environment } \\
\text { to suit their needs }\end{array}$ & $3.00^{\mathrm{b}}$ & 1.20 & $\cdots$ \\
\hline $\begin{array}{l}\text { ORDER } \\
\text { - Agriculture brings order to land that was once wilderness } \\
\text { - No one has the right to tell farmers what practices to use } \\
\text { on their land } \\
\text { - The balance of nature is very delicate and easily upset }\end{array}$ & $3.03^{b}$ & 0.77 & 0.49 \\
\hline
\end{tabular}

(a) Scale was $1=$ strongly disagree, $2=$ agree, $3=$ neutral, $4=$ agree, $5=$ strongly agree.

(b) Item scale reversed for analysis.

Means not sharing a superscript are significantly different from one another at $p \leq .05$.

Table 2

Mean scores on "frontier mentality" attitudes categories

\begin{tabular}{lllll}
\hline Category & & $\begin{array}{l}\text { Organic } \\
\text { Farmers (a) }\end{array}$ & $\begin{array}{l}\text { Conventional } \\
\text { Farmers (b) }\end{array}$ & $\begin{array}{l}\text { T-Test } \\
\text { Statistic }\end{array}$ \\
\hline \multirow{2}{*}{ HARMONY } & Mean $=$ & $4.24^{\mathrm{a}}$ & 3.24 & $\begin{array}{l}t=4.17, d f=21.2, \\
p \leq .0001\end{array}$ \\
\hline \multirow{2}{*}{ S.D. $=$} & 0.66 & 0.53 & \\
\hline \multirow{2}{*}{ RIGHT } & Mean $=$ & $4.09^{\mathrm{a}}$ & 3.46 & not significant \\
\hline & S.D. $=$ & 0.83 & 1.27 & not significant \\
ORDER & Mean $=$ & $3.20^{\mathrm{a}} \mathrm{b}$ & 2.83 & \\
\hline
\end{tabular}

(a) Means not sharing a superscript are significantly different from one another at $p \leq .05$, with Harmony and Right significantly different at $p \leq .06$.

(b) All pairwise mean comparisons are not significant at $p \leq .05$

(means $=4.24$ and 4.09 , respectively) more strongly than Right (mean $=3.20$ ) and Order $($ mean $=2.81)$. 
Table 3

Mean scores on farmer's appreciation of nature items

\begin{tabular}{|c|c|c|c|c|}
\hline Stem Question / Item (a) & & $\begin{array}{l}\text { Organic } \\
\text { Farmers }\end{array}$ & $\begin{array}{l}\text { Conventional } \\
\text { Farmers }\end{array}$ & $\begin{array}{l}\text { T-Test } \\
\text { Statistic }\end{array}$ \\
\hline $\begin{array}{l}\text { How closely do you observe } \\
\text { the following on your farm? } \\
\text { RAINFALL }\end{array}$ & $\begin{array}{l}\text { Mean }= \\
\text { S.D. }=\end{array}$ & $\begin{array}{l}4.67 \\
0.49\end{array}$ & $\begin{array}{l}5.00 \\
0.00\end{array}$ & (b) \\
\hline CLOUD TYPES & $\begin{array}{l}\text { Mean }= \\
\text { S.D. }=\end{array}$ & $\begin{array}{l}3.75 \\
0.96\end{array}$ & $\begin{array}{l}3.69 \\
0.85\end{array}$ & not significant \\
\hline SOIL QUALITY & $\begin{array}{l}\text { Mean }= \\
\text { S.D. }=\end{array}$ & $\begin{array}{l}4.83 \\
0.39\end{array}$ & $\begin{array}{l}4.69 \\
0.48\end{array}$ & not significant \\
\hline INSECT POPULATIONS & $\begin{array}{l}\text { Mean }= \\
\text { S.D. }=\end{array}$ & $\begin{array}{l}4.33 \\
1.15\end{array}$ & $\begin{array}{l}3.77 \\
1.01\end{array}$ & not significant \\
\hline WILDLIFE & $\begin{array}{l}\text { Mean }= \\
\text { S.D. }=\end{array}$ & $\begin{array}{l}4.50 \\
0.67\end{array}$ & $\begin{array}{l}4.00 \\
0.91\end{array}$ & not significant \\
\hline CHANGE OF SEASONS & $\begin{array}{l}\text { Mean }= \\
\text { S.D. }=\end{array}$ & $\begin{array}{l}4.75 \\
0.62\end{array}$ & $\begin{array}{l}4.08 \\
1.12\end{array}$ & $\begin{array}{l}t=1.88, \mathrm{df}=19.1 \\
p \leq 0.08\end{array}$ \\
\hline SOIL EROSION & $\begin{array}{l}\text { Mean }= \\
\text { S.D. }=\end{array}$ & $\begin{array}{l}4.83 \\
0.58\end{array}$ & $\begin{array}{l}4.54 \\
0.52\end{array}$ & not significant \\
\hline WATER QUALITY & $\begin{array}{l}\text { Mean }= \\
\text { S.D. }=\end{array}$ & $\begin{array}{l}4.08 \\
1.38\end{array}$ & $\begin{array}{l}4.38 \\
0.77\end{array}$ & not significant \\
\hline
\end{tabular}

(a) Scale was $1=$ not at all, $2=$ not very closely, $3=$ neutral, $4=$ somewehat closely, $5=$ very closely.

(b) Due to the lack of variance among conventional farmers, the $t$-test statistic could not be calculated.

\section{Appreciation of Nature}

The respondents were asked about some of the signs of nature that matter to them as farmers. Table 3 shows the results from Student's $t$-test analyses with regard to eight Appreciation of Nature items measured using a Likert scale. Both organic and conventional farmers scored relatively high on all eight items, indicating that those signs of nature are clearly noticed on their farms. There was no significant difference between the organic and conventional responses with regard to Cloud Types, Soil Quality, Insect Populations, Wildlife, Soil Erosion, or Water Quality at $p \leq .05$. Given the lack of variance among conventional farmers with regard to Rainfall (i.e. all conventional farmers answered "very closely"), it was not possible to calculate the $t$-test statistics. The organic farmers also scored high on this item (mean=4.65). With regard to the Change of Season item, the analysis suggested a possible, although statistically non-significant, trend for organic farmers to be more sensitive to changes of seasons than conventional farmers $(t=1.88, d f=19.1, p \leq 0.08)$. 
Table 4

Attitudes regarding the benefits of farming

\begin{tabular}{lll}
\hline Stem Question / Item & Organic Farmers & Conventional Farmers \\
$\begin{array}{l}\text { What do you like most } \\
\text { about farming? }\end{array}$ & \\
LIVING ETHICALLY & $33 \%$ & $8 \%$ \\
COMMUNITY & $25 \%$ & $0 \%$ \\
THE WORK ITSELF & $17 \%$ & $31 \%$ \\
HERITAGE AND IDENTITY & $0 \%$ & $15 \%$ \\
\hline & & \\
Most Common responses of all Farmers & \\
INDEPENDENCE & $52 \%$ & \\
NATURE & $36 \%$ & \\
BEING OUTDOORS & $36 \%$ & \\
PRIDE IN PRODUCT & $24 \%$ & \\
\hline
\end{tabular}

\section{Benefits of Farming}

When asked what they liked most about farming, the qualitative analysis suggested that farmers from both sample groups responded similarly (see Table 4). ${ }^{2}$ Farmers typically gave more than one answer, so it was not possible to discern which of the themes cited was most liked.

Two themes distinguished the organic from conventional growers. Among organic growers, "living ethically" was cited as what they liked most about farming with the same frequency (33\%) as "nature" and "being outdoors," second only to "independence $(50 \%)$. As one organic farmer explained, "Farming allows me to be of service to the earth, contributing to a healing process." In contrast, only one (8\%) conventional grower mentioned the ethics or spirituality of farming as one of the things liked most. Additionally, one-fourth (25\%) of the organic growers made reference to enjoying the farming community - sharing and participating with farmers and the people who purchase their products. None of the conventional farmers mentioned community in their response. In contrast, heritage and identity, mentioned by $15 \%$ of the conventional farmers received no mention by the organic farmers.

The most frequent response for both groups was the independence farming allows and "being one's own boss" (52\% of all the farmers interviewed). Over one-third of all the farmers ( $36 \%$ ) referred to some aspect of nature in their response while an equally common response (36\%) was being outdoors. Nearly a quarter of all farmers (24\%) expressed pride in the products produced. There were a couple of ather items at a much lower level of endorsement. Twenty percent liked the process itself, "just seeing things grow." The same number (20\%) enjoyed the sense of control farming gives. 
Table 5

Attitudes about leaving their farms

\begin{tabular}{lcc}
\hline Stem Question / Item & Organic Farmers & Conventional Farmers \\
\hline $\begin{array}{l}\text { If you had to leave your farm, } \\
\text { what would you miss the most? }\end{array}$ & $33 \%$ & \\
THE COUNTRYSIDE & $25 \%$ & $8 \%$ \\
BEING OUTDOORS & $8 \%$ & $8 \%$ \\
OPEN SPACES & & $23 \%$ \\
\hline & & \\
Most Common Responses of all Farmers: & \\
NATURE & $28 \%$ & \\
INDEPENDENCE & $20 \%$ & \\
\hline
\end{tabular}

\section{Hindsight: Farmers' Attitudes about Leaving Their Farms}

Farmers were asked what they would miss the most if they had to leave their farms (see Table 5). Logically, one would expect farmers would miss the same things they had stated they liked most in their responses to the earlier question discussed above. In some respects, the answers did correspond. In general, however, responses to this question were more poetic than responses to the previous one, with more descriptive references to nature and less emphasis on individual actions as a farmer. $\mathrm{Na}$ ture was the most frequently occurring concept in responses from organic and conventional farmers (28\%), and was said with almost equal frequency by both (33\% of organic farmers and $23 \%$ of conventional farmers). Independence was also highly endorsed by both groups of farmers answering this question (20\%), but appeared with less frequency than it had in response to the earlier question. Likewise, the sense of control over one's destiny and resources that had been important to both groups of farmers in answering what they liked about farming was almost completely absent from their responses regarding what they would miss about farming (17\% of organic growers and $23 \%$ of conventional growers liked the control farming gives them; $8 \%$ of organic growers and none of conventional growers would miss the control). Essentially, what farmers in general like most about farming is the independence it gives them, but what they imagine they would miss most is nature.

In addition, none of the themes that distinguished the two groups of farmers on the earlier question was prominent when farming was viewed in hindsight. For onethird (33\%) of the organic farmers, "living ethically" was one of the things they liked most about farming. When farming was viewed in hindsight, however, only $8 \%$ of the organic farmers mentioned they would miss "living ethically" if they had to leave their farms. This finding makes sense because leaving the farm would not prevent a person from living an ethical lifestyle. Also in contrast to their responses to the earlier question, none of the organic growers mentioned the farming community as 
Table 6

Attitudes regarding the drawbacks of farming

\begin{tabular}{lcc}
\hline Stem Question / Item & Organic Farmers & Conventional Farmers \\
\hline $\begin{array}{l}\text { What do you like least } \\
\text { about farming? }\end{array}$ & & \\
EQUIPMENT & $25 \%$ & $8 \%$ \\
$\begin{array}{l}\text { STRESS/DEALING WITH } \\
\text { THE UNEXPECTED }\end{array}$ & $8 \%$ & $31 \%$ \\
EXPENSE & $8 \%$ & $23 \%$ \\
\hline
\end{tabular}

Most Common Responses of all Farmers:

INADEQUATE FINANCIAL

REWARD

something they would miss if they no longer farmed.

In response to this question, the two groups of farmers distinguished themselves by how they depicted the setting they would miss. Organic farmers were most likely to respond that they would miss nature, the countryside and being outdoors (33\%, $33 \%$ and $25 \%$, respectively). Conventional farmers were most likely to respond that they would miss nature $(23 \%)$ and the open spaces $(23 \%)$. While organic farmers frequently made reference to the quiet, peace and fresh air of the country, conventional farmers were more likely to talk about just being outdoors and to make specific reference to the "open spaces."

\section{Drawbacks of Farming}

As with the benefits of farming question, farmers from both groups particularly disliked one aspect of farming (see Table 6 ). Over half $(52 \%)$ of all farmers cited lack of financial reward as the main drawback of farming. While this was the most common response given by both groups of farmers, it was mentioned with greater frequency by the conventional growers $(62 \%)$ than by the organic growers $(42 \%)$. An additional 23\% of the conventional growers responded that the expense for inputs, equipment, etc. was what they liked least about farming. Only $8 \%$ of the organic growers gave this response. In total, $85 \%$ of the conventional farmers mentioned some sort of financial consideration, compared with $50 \%$ of organic farmers. Among conventional growers, the stress associated with the unexpected (such as weather) was the next most frequently cited drawback of farming. Almost one-third (31\%) of conventional growers included "stress" in their response, compared to only $8 \%$ of organic growers. After "lack of financial reward," the next most frequent response among organic growers (25\%) involved equipment (maintenance, noise, etc.). While disliking farming equipment was not unique to organic growers ( $8 \%$ of conventional growers mentioned equipment), it was only the organic farmers who mentioned having considered draft animals as a superior alternative. One conventional 
Table 7

Attitudes regarding satisfaction with farm life

\begin{tabular}{llc}
\hline Stem Question / Item & Organic Farmers & Conventional Farmers \\
\hline $\begin{array}{l}\text { How satisfying would you say your } \\
\text { life has been compared to other } \\
\text { people you know? What makes it } \\
\text { more or less satisfying? }\end{array}$ & & \\
MORE SATISFYING & $33 \%$ & $15 \%$ \\
NOT HAVING ANY DEBT & $25 \%$ & $0 \%$ \\
FEEL FORTUNATE & $17 \%$ & $0 \%$ \\
LACK OF FINANCIAL SUCCESS & $0 \%$ & $31 \%$ \\
LIFE IS SATISFACTORY & $0 \%$ & $15 \%$ \\
"ENJOY" WHAT THEY DO & $0 \%$ & $15 \%$ \\
FRUSTRATED BY LACK & $0 \%$ & $15 \%$ \\
OF FREEDOM & & $15 \%$ \\
FARMING IS NOT A CHOICE & $0 \%$ &
\end{tabular}

Most Common Responses of all Farmers:

SATISFYING (but can't $56 \%$

judge others' lives)

DOING WHAT THEY

$24 \%$

WANT TO BE DOING

farmer's response summed up many of the farmers' concerns: ". . expense-I don't know why I worry about money so much. Probably because I don't have any. The unexpected-like breakdowns and the weather. Trying to get everything to work right is quite a job. You expect it, but it never happens."

\section{Satisfaction with Farm Life}

Responses to the question, "How satisfying would you say your life has been compared to other people you know?" were almost unanimously positive (see Table 7). Most farmers from both groups (56\%) expressed satisfaction with their lives, but were reluctant to judge how satisfied other people they knew were. About one-fourth of the farmers (24\%) felt their lives were more satisfying than others they knew, though this response was more common among organic farmers (33\% for organic farmers and $15 \%$ for conventional farmers). An equally frequent response (24\%) was simply that they were doing what they wanted to do.

Although answers for both groups were similar, conventional farmers were generally less enthusiastic in their responses. For example, whereas over one-fourth of the organic growers used more positive terms like "lucky" and "fortunate" to de- 
Table 8

Attitudes regarding relationship with the land

\begin{tabular}{lll}
\hline Stem Question / Item & Organic Farmers & Conventional Farmers \\
\hline $\begin{array}{l}\text { Do you believe farmers have a } \\
\text { different relationship with the land } \\
\text { that those who don't farm? How? }\end{array}$ & & \\
$\begin{array}{l}\text { FARMERS ARE IN CLOSER CONTACT } \\
\text { WITH THE LAND }\end{array}$ & $33 \%$ & $15 \%$ \\
$\begin{array}{l}\text { SOME NON-FARMERS ARE LIKE } \\
\text { FARMERS }\end{array}$ & $25 \%$ & $15 \%$ \\
MENTIONED SOIL & $8 \%$ & $38 \%$ \\
PROTECT OR TAKE CARE OF THE & & \\
LAND & $8 \%$ & $38 \%$ \\
FARMERS RESPECT THE LAND & $0 \%$ & $15 \%$ \\
\hline $\begin{array}{l}\text { MOst Common Responses of all Farmers: } \\
\text { YES, THEY DO HAVE A DIFFERENT }\end{array}$ & & \\
RELATIONSHIP & $80 \%$ & \\
FARMERS HAVE GREATER \\
AWARENESS AND APPRECIATION OF \\
SURROUNDINGS
\end{tabular}

scribe how they felt about their occupations, almost one-third of the conventional farmers used somewhat less positive terms like "satisfactory" or "fairly happy" to describe their lives as farmers. Some conventional farmers even seemed to have resigned themselves to farming. Paradoxically, while they valued the independence of farming, they resented the lack of freedom and leisure associated with their occupation. Independence and lack of freedom seem to co-exist in farming and farmers' minds, each an outcome of the enormous responsibility individual farmers bear for the "success" of their operation. As one conventional farmer said, "I've got this ambivalence about it [farming] . . There's some joy in it, but it's mostly just a resignation that this is what I'm going to spend the rest of my life doing. Farming is very unforgiving. I don't like not having the freedom." Additionally, financial considerations seemed to factor differently into the satisfaction both groups felt with farming. For instance, nearly one-third (31\%) of the conventional sample mentioned their failure to achieve financial success as a factor negatively affecting their satisfaction with their lives. In contrast, one-fourth $(25 \%)$ of the organic farmers positively related not owing money on their farm to their personal satisfaction. 


\section{Farmers' Relationship with the Land}

Farmers were asked if they believed farmers have a different relationship with the land than those who don't farm (see Table 8). A majority of all farmers interviewed ( $80 \%$ overall; $75 \%$ of organic farmers and $85 \%$ of conventional farmers) believed they do have a different relationship with the land. All of the farmers interviewed believed at least some farmers have a different relationship with the land than non-farmers. In explaining the difference between farmers and non-farmers, nearly one-third (32\%) of all farmers indicated that farmers have a greater awareness and appreciation of their surroundings than non-farmers. As one conventional farmer described the relationship, "We tend to admire nature more because we're closer to it. We pick up on the little things. When other people go down the road and see a tree, we see an oak or maple." This sense of awareness and appreciation was more often mentioned by organic farmers ( $42 \%$ ) than by the conventional farmers (23\%). A large number $(28 \%)$ also attributed the difference to farmers' seeing the land as their livelihood - something they use to grow crops and earn a living.

Organic farmers were more likely than conventional farmers to believe that farming is not a necessary prerequisite to appreciating the land. One-fourth of them (25\%) acknowledged that some non-farmers also have a very special relationship with the land, whereas only $15 \%$ of the conventional farmers included this in their response. This belief in the primacy of farming could be accounted for by conventional farmers' endorsement of two additional concepts in explaining the difference between farmers and non-farmers. First, $38 \%$ of conventional farmers specifically mentioned the soil in answering this question. They frequently made references to touching the soil-actually making contact with it. Only $8 \%$ of the organic farmers included "the soil" in their response. Second, 38\% of the conventional farmers defined farmers' relationship with the land as a caretaker role. They spoke of "protecting" and "caring for" the land. Some even anthropomorphized the land, comparing it to a member of the family. Again, only $8 \%$ of the organic farmers made similar references.

\section{Discussion}

\section{Farmers' Conflicted Attitudes}

The findings shown above help to explain the paradoxical nature of farmers attitudes about farming. The farmers we interviewed have a strong appreciation for nature and the rural environment. They view contact with nature as a benefit of farming, would miss this contact if they didn't farm, and generally believe that people should live in harmony with nature. Being outdoors and experiencing nature were the second most frequently cited benefits of farming. Perhiaps more telling, nearly all farmers we interviewed mentioned some aspect of nature as what they would miss most if they stopped farming. In addition, they believe that farmers have a different relationship with the land from that of non-farmers, with a greater awareness and appreciation of natural phenomena. This appreciation was very apparent 
in the interviews, as the most laconic of farmers waxed poetic in describing what would be missed about farming. Even the conventional farmer whose overall score on conservation practices was the lowest of the sample spoke mystically of the change of seasons, recounting stories of perfectly-coloured trees observed while harvesting. Most of these people report being satisfied with their lives as farmers. These factors support the notion of a land ethic in operation whereby farmers see themselves as stewards of the rural landscape.

Our hypothesis that all farmers would appreciate and attend to nature was drawn primarily from the philosophical and historical literature, rather than empirical data. The image of farmers as people living close to nature is deeply embedded in several philosophical traditions in the U.S., but little empirical research has looked at how closely farmers live with nature. This study supports Molnar and Duffy s (1987) findings that farmers see themselves as understanding and working with nature. While orientation towards nature has frequently been considered to fall on a spectrum between utilitarian and appreciative (Bultena et al., 1982; Tremblay and Dunlap, 1978), research efforts have focused on measuring utilitarianism rather than appreciation. For example, Van Liere and Dunlap (1981), Arcury et al. (1986), and Buttel and Flinn $(1974 ; 1978)$ all concluded that urbanism was positively related to environmental concern. They attributed these findings to the utilitarian orientation of rural residents, who are more likely to be engaged in extractive occupations

Journal of Agricultural and Environmental Ethics 1996, 9(2), 93-113

propriate characterization of environmental orientation.

At the same time, the farmers in this study view independence as a main benefit of farming. In addition, they view a lack of financial reward as a main drawback of farming. The simultaneous force of an independent spirit and a financial hardship forces important compromises in the stewardship ideal. The notion of the family farm is an important aspect of American heritage and encompasses those values that many believe to be what this country stands for-rugged individualism and selfsufficiency to name but two. Yet, with the increase in large-scale, capital-intensive agriculture we have seen this family farm ideal threatened, questioned, and debated. This ambivalence is reflected here in the way farmers are simultaneously vulnerable to outside market forces and persistent in their farming independence. As Constance et al. point out (1990), the historical farming problem of excess supply, and the associated problems of low prices and unstable incomes, have shifted to problems of increased financial risk from incurred debt, product price instability, high inflation from input costs, and concentrated input and product markets. Consequently, farmers are faced with a variety of difficult decisions, coupled with a need to understand and often adapt to the changes and new technologies inherent in modern agriculture. It is no wonder that farmers attitudes about farming as a profession and a lifestyle are complex.

\section{Organic and Conventional Farmers}

This study suggests some important differences between conventional and organic 
farmers in the way they relate to farming and the natural environment. We predicted these two groups of farmers would have fundamentally different values with regard to the land and indeed this is supported by our results. Regarding the economic factors discussed above, conventional farmers report more stress in their lives. They have a greater concern for the financial aspects of farming and report stress as a major drawback of farming. In describing satisfaction with their lives, they mention financial considerations as a worry more than do the organic farmers. On the other hand, the conventional farmers view themselves in a caretaker role for the land more than do the organic farmers, this is illustrated most vividly by their greater concern for the soil as a resource.

However, the organic farmers showed a somewhat different profile. They reported a greater concern for living ethically, a stronger perception of community, and more satisfaction with their lives. Their awareness and appreciation for nature and their relationship with the land were even stronger than among the conventional farmers. We had hypothesized that conventional farmers would embrace the frontier mentality that humans should overcome nature, and the Jeffersonian belief in the rights of landholders. We also predicted that organic farmers would believe in living harmoniously with nature and be less concerned with their rights as landholders. These predictions are supported by our findings on the frontier mentality portion of the survey. While both groups somewhat reject the frontier mentality of conquering nature, organic farmers were significantly more supportive of the idea that humans should live in harmony with nature.

Finally, we also predicted that conventional farmers would feel more strongly about their rights as landholders than organic farmers. The data generally support this prediction. Organic farmers are not very concerned about their absolute rights, while conventional farmers are basically neutral on this issue. On a more practical level, qualitative analysis indicated organic and conventional farmers in agreement that, regardless of their rights as property holders, government should have only a limited role in regulating farming practices. Organic farmers generally agreed that farmers do not have the right to damage the land. In addition, they tended to disagree with or were neutral about the statement that no one has the right to tell farmers what to do. Conventional farmers means on both categories were only slightly above neutral. Taken together, these findings suggest that organic farmers are willing to have their rights limited but do not necessarily trust the government to do so, while conventional farmers are less willing to have their rights limited and also distrust government limitations.

In conclusion, no simple pattern of attitudes or beliefs characterizes the farmers in this study. Instead we are left with a tension at the level of individual farmers that mirrors the broader cultural and philosophical debate over the interaction of environmental and agricultural values and beliefs. And while organic and conventional farmers do differ, their similarities may be as, or more, important. It would seem that promoting environmentally sound agriculture need not target only one subgroup of farmers. 


\section{Acknowledgment}

The authors thank the farmers interviewed for their insightful comments and acknowledge funding support from the University of Michigan School of Natural Resources and Environment.

\section{Notes}

1 A copy of the survey instrument can be obtained by contacting the third author at the School of Natural Resources and Environment, University of Michigan, 430 East University Avenue, Ann Arbor, MI 48109-1115.

2 All tables describing qualitative results are constructed using the same format. Concepts that appear with markedly different frequency in responses given by organic and conventional farmers are reported in the top portion of the tables. Concepts that appeared with greater frequency in organic farmers' responses are reported first, followed by concepts more common in conventional farmers' responses. When certain concepts were highly endorsed by both groups of farmers, those concepts are reported in the lower portion of the tables.

\section{References}

Anderson, Molly. 1990. Farming with Reduced Synthetic Chemicals in North Carolina. American Journal of Alternative Agriculture 5(2): 60-68.

Arcury, Thomas A., Timothy P. Johnson, and Susan J. Scollay. 1986. Ecological Worldview and Environmental Knowledge: The "New Environmental Paradigm." Journal of Environmental Education 17: 35-40.

Beus, Curtis E., and Riley E. Dunlap. 1990. Conventional Versus Alternative Agriculture: The Paradigmatic Roots of the Debate. Rural Sociology 55(4): 590616.

- 1991. Measuring Adherence to Alternative Vs. Conventional Agricultural Paradigms: A Proposed Scale. Rural Sociology 56(3): 432-460.

Bultena, Gordon, Eric Hoiberg, Don Albrecht, and Peter Nowak. 1982. Land Use Planning: A Study of Farm and City Perspectives. Journal of Soil and Water Conservation 37(6): 341-344.

Bultena, Gordon, Peter Nowak, Eric Hoiberg, and Don Albrecht. 1981. Farmers' Attitudes toward Land Use Planning. Journal of Soil and Water Conservation 36(1): 37-41.

Buttel, Frederick H., and William L. Flinn. 1974. The Structure of Support for the Environmental Movement, 1968-1970. Rural Sociology 39: 56-69.

- 1978 Economic Growth Versus the Environment: Survey Evidence. Social Science Quarterly 57(September): 410-420.

Buttel, Frederick H., and Gilbert W. Gillespie, Jr. 1988. Preferences for Crop Production Practices among Conventional and Alternative Farmers. Journal of Alternative Agriculture 3: 11-17.

Buttel, Frederick H., Gilbert W. Gillespie, Jr., Oscar W. Larson III, and Craig K. Harris. 1981. The Social Bases of Agrarian Environmentalism: A Comparative Analysis of New York and Michigan Farm Operators. Rural Sociology 46(3): $391-410$.

Callicott, J. Baird. 1987. The Scientific Substance of the Land Ethic. In Aldo Leopold: The Man and His Legacy, edited by Thomas Tanner, pp. 87-106. Ankeny, IA: 
IA: Soil Conservation Society of America.

Carr, Susan, and Joyce Tait. 1991. Differences in the Attitudes of Farmers and Conservationists and their Implications. Journal of Environmental Management 32: 281-294.

Constance, Douglass H., Jere L. Gilles, and William D. Heffernan. 1990. Agrarian Policies and Agricultural Systems in the United States. In Agrarian Policies and Agricultural Systems, edited by Alessandro Bonanno, pp. 9-75. Boulder, CO: Westview Press.

Crevecoeur, J. Hector St. John. 1904 [1784]. Letters from an American Farmer. New York: Fox, Duffield \& Company.

Cronbach, L.J. 1951. Coefficient Alphe and the Internal Structure of Tests. Psychometrika 16: 297-335.

Crosson, Pierre. 1982. Diverging Interests in Soil Conservation and Water Quality: Society vs. the Farmer. In Perceptions, Attitudes and Risk: Overlooked Variables in Formulating Public Policy on Soil Conservation and Water Quality. Washington, DC: Economic Research Service. (February).

Esseks, J. Dixon, Steven E. Kraft, and Lucy K. Vinis. 1990. Agriculture and the Environment: A Study of Farmers' Practices and Perceptions. Washington, DC: The American Farmland Trust.

Flader, Susan. 1987. Aldo Leopold and the evolution of a land ethic. In Aldo Leopold: The Man and His Legacy, edited by Thomas Tanner, pp. 3-24. Ankeny, IA: Soil Conservation Society of America.

Hall, Trish. 1992. In 90's Cuisine, the Farmer is the Star. The New York Times. (July 8), p. C1.

Hargrove, C. Eugene, and J. Baird Callicott. 1990. Leopold's "Means and Ends in Wildlife Management": A Brief Commentary. Environmental Ethics 12: 333337.

Harris, Craig K., Sharon E. Powers, and Frederick H. Buttel. 1980. Myth and Reality in Organic Farming: A Profile of Conventional and Organic Farmers in Michigan. Newsline 8: 33-43.

Hendee, John C. 1969. Rural-Urban Differences Reflected in Outdoor Recreation Participation. Journal of Leisure Research 1(Autumn): 333-341.

Leopold, Aldo. 1949. A Sand County Almanac. New York: Oxford University Press, 1949; reprint ed., New York: Robert Finch, 1987.

Little, Charles E. 1985. In a Landscape of Hope. Wilderness (Spring): 21-30.

Meine, Curt. 1987. The Farmer as Conservationist: Leopold on Agriculture. In Aldo Leopold: The Man and His Legacy, edited by Thomas Tanner, pp. 39-52. Ankeny, IA: Soil Conservation Society of America.

Molnar, Joseph J., and Patricia A. Duffy. 1987. Urban and Suburban Residents' Perceptions of Farmers and Agriculture. In Sustaining Agriculture Near Cities, edited by W. Lockeretz, pp. 119-131. Boston: Soil and Water Conservation Society of America.

Napier, Ted L., and D. Lynn Forster. 1982. Farmer Attitude and Behavior Associated with Soil Erosion Control. In Soil Conservation Policies, Institutions and Incentives, edited by H.G. Halcrow, E.O. Heady and M.L. Cotner. Ankeny, IA: Soil Conservation Society of America.

Nash, Roderick. 1982. Wilderness and the American Mind. Binghamton, NY: VailBallou Press.

1987. Aldo Leopold and the Limits of American Liberalism. In Aldo Leopold: The Man and His Legacy, edited by Thomas Tanner, pp. 53-86. Ankeny, IA: 
Soil Conservation Society of America.

Patton, M.Q. 1990. Qualitative Evaluation and research Methods. Newbury Park, CA: Sage Publications.

Peterson, Tarla Rai. 1991. Telling the Farmers' Story: Competing Responses to Soil Conservation Rhetoric. Quarterly Journal of Speech 77: 289-308.

Piasecki, Bruce. 1982. Pastoral Ideals and Environmental Problems: An Interview with Leo Marx. The Amicus Journal (Fall): 56-61.

Stegner, Wallace. 1985. Living on Our Principal. Wilderness (Spring): 15-20.

Tremblay, Kenneth R., and Riley E. Dunlap. 1978. Rural-urban Residence and Concern with Environmental Quality: A Replication and Extension. Rural Sociology 43(3): 474-491.

Van Liere, Kent D., and Riley E. Dunlap. 1981. Environmental Concern: Does it Make a Difference How it's Measured? Environment and Behavior 13(6): 651676.

Westmacott, Richard. 1983. The Conservation of Farmed Landscapes: Attitudes and Problems in the United States and Britain. Landscape Design (August): 1114.

Wojcik, Jan. 1989. The Arguments of Agriculture: A Casebook in Contemporary Agricultural Controversy. West Lafayette, IN: Purdue University Press. 